\title{
Agar hydrogel with silver nanoparticles to prolong the shelf life of Fior di Latte cheese
}

\author{
A. L. Incoronato, ${ }^{*}$ A. Conte,${ }^{*}+$ G. G. Buonocore, $\neq$ and M. A. Del Nobile ${ }^{*} \dagger^{1}$ \\ *Department of Food Science, University of Foggia, Via Napoli, 25 - 71100 Foggia, Italy \\ †Istituto per la Ricerca e le Applicazioni Biotecnologiche per la Sicurezza e la Valorizzazione dei Prodotti Tipici e di Qualità, \\ Università degli Studi di Foggia, Via Napoli, 25 - 71100 Foggia, Italy \\ ‡Institute for Composites and Biomedical Materials, P.le E. Fermi, 1, 80055 Portici (Naples), Italy
}

\begin{abstract}
The objective of this work was to evaluate the effectiveness of an antimicrobial packaging system containing active nanoparticles on the quality deterioration of Fior di Latte cheese. To this aim, 3 concentrations of silver montmorillonite embedded in agar were used. The cell loads of spoilage and useful microorganisms were monitored during a refrigerated storage period. Moreover, cheese sensory quality (i.e., odor, color, consistency, and overall quality) was evaluated by means of a panel test. Results showed that the active packaging system markedly increased the shelf life of Fior di Latte cheese, due to the ability of silver cations to control microbial proliferation, without affecting the functional dairy microbiota and the sensory characteristics of the product. The active packaging system developed in this work could be used to prolong the shelf life of Fior di Latte and boost its distribution beyond local market borders.
\end{abstract}

Key words: Fior di Latte, nanocomposite, shelf life

\section{INTRODUCTION}

Fior di Latte cheese is a mild, soft, white cheese made by a pasta filata process (Altieri et al., 2005) that, because of its high moisture content, is very perishable and has a short shelf life. Although Fior di Latte cheese receives a heat treatment during curd stretching, postprocessing contamination by microorganisms may occur, causing cheese spoilage and a health risk to consumers (Spano et al., 2003). Undesirable microorganisms such as pseudomonads, coliforms, yeasts, and molds may cause defects in flavor, texture, and appearance of cheese and result in economic losses (Gammariello et al., 2008; Conte et al., 2009; Del Nobile et al., 2009).

Received September 14, 2010.

Accepted December 21, 2010

${ }^{1}$ Corresponding author: ma.delnobile@unifg.it
The higher demand for fresh-like products promotes the search for new technologies to preserve food. One of the most recent potential approaches to prolong the shelf life of fresh products is the use of active packaging systems (Lopez-Rubio et al., 2006; Conte et al., 2007; Coma, 2008).

Silver nanoparticles are potential candidates for active packaging, thus broadening their application in ensuring food quality and safety (Damm et al., 2008; Fernandez et al., 2009; Li et al., 2009; Incoronato et al., 2010). Nanotechnology is emerging as a rapidly growing field with great potential application for the purpose of manufacturing new materials at a nanoscale level (Albrecht et al., 2006; Bjarnsholt et al., 2007). Metallic nanoparticles are promising because they show good antibacterial properties due to their large surface area to volume ratio (Gong et al., 2007). Different types of nano-materials such silver, zinc, titanium (Retchkiman-Schabes et al., 2006), magnesium, gold (Gu et al., 2003), and copper have been evaluated; silver nanoparticles have proved to be effective against bacteria, viruses, and other eukaryotic microorganisms (Gong et al., 2007; Darroudi et al., 2009). The antimicrobial activity of silver is dependent on the silver cation $\mathrm{Ag}^{+}$, which binds strongly to electron donor groups in biological molecules containing sulfur, oxygen, or nitrogen. Hence, the silver-based antimicrobial polymers have to release $\mathrm{Ag}^{+}$to a pathogenic environment to be effective. The oxidation of the metallic silver to the active species $\mathrm{Ag}^{+}$is possible through the interaction of silver with water molecules. A steady and prolonged release of silver biocide at a concentration level capable of rendering antimicrobial efficacy is a key factor for designing this class of materials. Silver ions are highly reactive, because they bind to tissue proteins and bring structural changes in the bacterial cell wall and nuclear membrane leading to cell distortion and death (Lansdown, 2002; Castellano et al., 2007). Studies of inhibition of silver ions against gram-positive and gram-negative bacteria have been reported (Feng 
et al., 2000; Panacek et al., 2006; Kascatan-Nebioglu et al., 2007; Hindi et al., 2008). In particular, Incoronato et al. (2010) demonstrated the effectiveness of silver montmorillonite (Ag-MMT) nanoparticles, obtained by allowing silver ions from nitrate solutions $\left(\mathrm{AgNO}_{3}\right)$ to replace the exchangeable $\mathrm{Na}^{+}$counter ions in the natural sodium montmorillonite, against food-borne bacteria, thus promoting nanocomposites for food applications.

The silver supporting materials have also potential for use in the field of food packaging; however, the European Union safety regulation that limits the amount of silver ions in food matrices to $0.05 \mathrm{mg}$ of $\mathrm{Ag} / \mathrm{kg}$ (Fernandez et al., 2009) must be taken into account. The recent literature reports some studies dealing with the use of materials loaded with silver nanoparticles to improve the shelf-life of foodstuffs. An et al. (2008) investigated the application of silver nanoparticlespolyvinylpyrrolidone (PVP) as a coating for green asparagus, showing an increase in shelf life of about $10 \mathrm{~d}$ at $2^{\circ} \mathrm{C}$. Fernandez et al. (2009) used cellulose-based absorbent pads as a vehicle for silver nanoparticles formed in situ by physical and chemical reduction methods. They showed that the hybrid materials developed by physical methods were effective against pathogenic microorganisms in vitro and showed very positive results in assays with chicken exudates.

To the best of our knowledge, no studies exist in the literature dealing with the use of active packaging systems based on silver nanoparticles to prolong the shelf life of dairy products. Among the available hydrogels, agar, a phycocolloid extracted from a group of red-purple marine algae (class Rhodophyceae), including Gelidium, Pterocladia, and Gracilaria genera, was chosen in this work as a matrix in which to embed silver nanoparticles. This agar gel is water-insoluble, nontoxic, biodegradable, and nonimmunogenic. The high macromolecular mobility of agar allows silver ions to diffuse in the environment and come in contact with the microorganisms. In fact, one of the factors governing the kinetics of silver ion release from a coating is the hydrophilic nature of the polymeric matrix (Kumar and Münstedt, 2005). Therefore, coatings with few hydrophilic components have limited water affinity and consequently exert lower efficacy against target microbial cells (Incoronato et al., 2010).

Therefore, the objective of this work was to assess the effectiveness of Ag-MMT nanoparticles loaded into an agar hydrogel in prolonging the shelf life of Fior di Latte cheese. To this aim, 3 concentrations of the Ag-MMT nanoparticles were tested. Microbial and sensorial quality of packaged cheese was monitored for about $10 \mathrm{~d}$.

\section{MATERIALS AND METHODS}

\section{Preparation of Ag-MMT Nanoparticles}

The unmodified pristine clay $\left(\mathrm{Na}^{+}\right.$-montmorillonite) was purchased from Southern Clay Products Inc. (Austin, TX). Silver montmorillonite nanoparticles were prepared by ion exchange reaction. Before the reaction, $5 \mathrm{~g}$ of Na-MMT was dispersed in $100 \mathrm{~mL}$ of a $0.2 \mathrm{M}$ $\mathrm{NaCl}$ solution for $4 \mathrm{~h}$ while stirring. The solid was then separated by centrifugation (model 4239R, ACL International, Milan, Italy) at a speed of $5,031 \times g$ for about $15 \mathrm{~min}$ and then washed 3 times with small amount of deionized water. The washed Na-MMT was brought in contact with silver nitrate solutions (Sigma-Aldrich, Milan, Italy) at different concentrations. In particular, Na-MMT was dispersed first in a $500 \mathrm{mg} / \mathrm{kg} \mathrm{AgNO}_{3}$ solution, at $70^{\circ} \mathrm{C}$ for $3 \mathrm{~h}$ under stirring, covering the top and side of the beaker to prevent the exposure to UV room light. The solid and liquid parts of the slurry were separated by centrifugation (model 4239R, ACL International) at 5,031 $\times g$ for $15 \mathrm{~min}$. Afterward, the collected solids were brought in contact with 1,000 and $5,000 \mathrm{mg} / \mathrm{kg} \mathrm{AgNO}$ solutions, following the procedure described previously. Finally, the collected sediment was washed with deionized water 3 times and allowed to dry overnight in a vacuum oven at $80^{\circ} \mathrm{C}$. Dried samples were ground until a homogeneous powder was obtained.

\section{Sample Packaging}

An agar-water mixture $(8 \mathrm{~g} / \mathrm{L})$ was obtained by dissolving agar (Oxoid, Milan, Italy) into distilled water and autoclaving (Steristeam, Reggio Emilia, Italy) at $121^{\circ} \mathrm{C}$ for $15 \mathrm{~min}$. After cooling to $50^{\circ} \mathrm{C}$, aliquots $(5$ $\mathrm{mL}$ ) of agar solution were added to different amounts of $\operatorname{Ag-MMT~}(10,15$, and $20 \mathrm{mg})$ and poured into tubs. The tubs were left to equilibrate to room temperature (active tubs). Two control treatments were used: the first (control) was packaged in a traditional packaging and the second (control-agar) was packaged in a tub coated with agar but without nanoparticles.

The Fior di Latte cheese samples (weighing $50 \mathrm{~g}$ and 5 to $7 \mathrm{~cm}$ in diameter) were manufactured in the cheese-making factory "Posta la via" (Foggia, Italy). The products were produced from pasteurized cow milk and acidified with $0.28 \%$ of lactic acid (80\%, Henan Jir, Tecno Milk, Bari, Italy) and $0.025 \%$ liquid rennet (strength 1:10,000). Cheese samples were brought to our laboratory under refrigeration conditions $\left(4^{\circ} \mathrm{C}\right)$. They were removed from their packages and introduced to the active tubs, the control-agar tubs, and the control tubs; then, traditional brine was poured into each tub to cover the cheese sample. The brine consisted of $2 \% \mathrm{NaCl}$ water solution. 
Determinations of microbial counts, $\mathrm{pH}$, and sensory quality were carried out before packaging and after 1 , $2,5,6$, and $7 \mathrm{~d}$ of storage under refrigerated conditions $\left(10^{\circ} \mathrm{C}\right)$.

\section{Microbiological Analyses}

Representative 10-g portions of each Fior di Latte cheese were blended with $90 \mathrm{~mL}$ of sterile saline solution $(9 \mathrm{~g} / \mathrm{L} \mathrm{NaCl})$ for 1 min by using a Stomacher Lab Blender 400 (Interscience, Saint Nom la Bretèche, France) and subjected to serial dilutions. The following conditions were adopted for the microbiological analyses: (1) total microbial count on plate count agar at $30^{\circ} \mathrm{C}$ for $48 \mathrm{~h}$; (2) coliforms on violet red bile agar at $37^{\circ} \mathrm{C}$ for $24 \mathrm{~h}$; (3) yeasts and molds on yeast peptone dextrose agar supplemented with chloramphenicol (0.1 $\mathrm{g} / \mathrm{L}$, Oxoid) incubated at $30^{\circ} \mathrm{C}$ for $48 \mathrm{~h}$; (4) coccusshaped lactic acid bacteria on M-17 agar at $37^{\circ} \mathrm{C}$ for 48 h; (5) lactobacilli on de Man, Rogosa, and Sharpe agar modified by adding $0.1 \mathrm{~g} / \mathrm{L}$ of cycloheximide (SigmaAldrich) after autoclaving at $121^{\circ} \mathrm{C}$ for $15 \mathrm{~min}$, at $37^{\circ} \mathrm{C}$ for $48 \mathrm{~h}$ anaerobically (Anaerogen Gas Pack, Oxoid); (6) Pseudomonas spp. on pseudomonas agar base, with added CFC selective supplement, and incubated at $25^{\circ} \mathrm{C}$ for $48 \mathrm{~h}$. All media used were from Oxoid. The analyses were carried out twice on 2 different batches of samples.

\section{Evaluation of $\mathrm{pH}$}

The $\mathrm{pH}$ was evaluated on Fior di Latte cheeses and on the conditioning solution by using a $\mathrm{pH}$ meter (MicropH 2001 model, Crison, Barcelona, Spain). Each value was the average of measures recorded on sample from 2 different batches.

\section{Sensory Analysis}

The sensory analysis of Fior di Latte cheese was determined by using the descriptive model of Corradini and Innocente (2002), with a few modifications. Consistency, color, and odor were the sensory attributes considered to evaluate the samples, by using a scale from 0 to 7 , where 4 indicated the attribute threshold for acceptability. On the basis of the above-mentioned attributes, a trained panel consisting of 6 judges was also asked to score the overall quality of the product using the same 0 to 7 scale.

\section{Modeling and Statistical Analysis}

The microbial acceptability limit (MAL; storage time at which the viable cell concentration reached its threshold value) and the sensorial acceptability limit (SAL; storage time at which the sensorial quality reached its threshold value) were obtained by fitting the Gompertz equation, as reparameterized by Corbo et al. (2006), to the experimental data, as reported in other works dealing with dairy products (Conte et al., 2009; Del Nobile et al., 2009).

To determine whether significant differences $(P<$ $0.05)$ existed among the mean values of the fitting parameters, one-way ANOVA and Duncan's multiple range test, with the option of homogeneous groups, were used to determine significance among differences. Statistica 7.1 for Windows (StatSoft Inc., Tulsa, OK) was used for this purpose.

\section{RESULTS AND DISCUSSION}

A new strategy based on the use of silver nanoparticles embedded into an agar hydrogel was proposed in this study to prolong the shelf life of Fior di Latte cheese. To this aim, the main quality sub-indices of Fior di Latte were monitored for $7 \mathrm{~d}$. In the following, results obtained for both microbiological and sensorial quality are reported and discussed separately.

\section{Microbiological Analyses}

Pseudomonas spp. and total coliforms are widely recognized as the main spoilage microorganisms of dairy products (Gammariello et al., 2008; Conte et al., 2009). In particular, alterations of dairy food products start to appear after proliferation of Pseudomonas spp. above $10^{6} \mathrm{cfu} / \mathrm{g}$ (Bishop and White, 1986). On the other hand, the presence of coliforms in cheese is an indication of poor sanitation; coliforms grow rapidly in cheese during the first days of storage and their metabolites include lactic acid, acetic acid, formic acid, succinic acid, ethanol, $\mathrm{H}_{2}$, and $\mathrm{CO}_{2}$. The production of gas results in early blowing; moreover, a cell load of coliforms of $10^{7}$ $\mathrm{cfu} / \mathrm{g}$ in retail prepacked cheese can cause gassy defects and swelling of the plastic bags (Tamine, 2000). For this reason, in this work, these 2 microbial groups were taken into account to assess the MAL of the product. Figure 1 shows the evolution of total coliforms over the storage time. As can be seen, total coliforms were able to proliferate in both the control samples. Conversely, Ag-MMT brought about a significant prolongation of the microbial lag phase, as well as a substantial reduction of the final loads attained in the stationary phase. The results of the fitting procedure are reported in Table 1, along with the statistical analysis. As can be observed, the viable cell concentration of the control samples increased above the threshold $\left(10^{5} \mathrm{cfu} / \mathrm{g}\right)$, whereas the cell counts of the active samples at all 


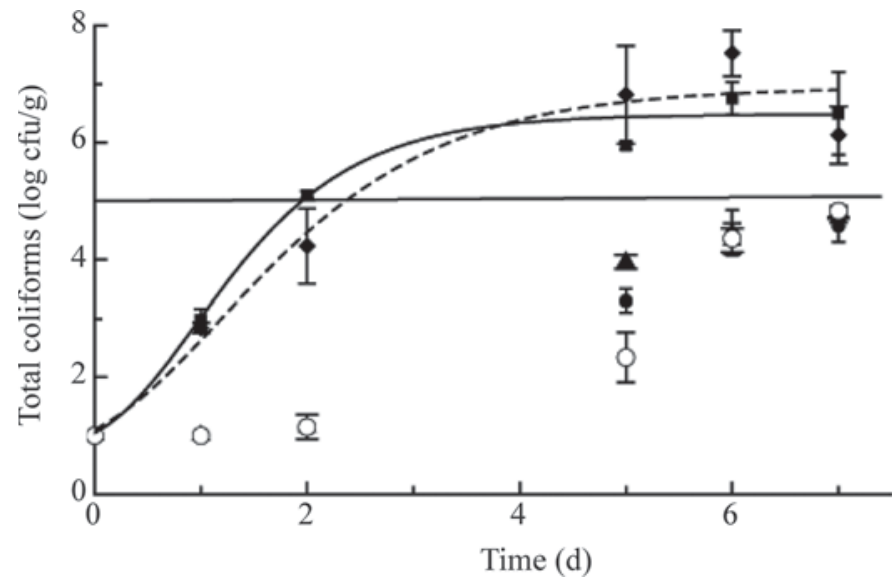

Figure 1. Evolution of total coliforms count in Fior di Latte cheese during the storage period. The curves are the best fit to the experimental data. = control sample packaged in the traditional packaging; $=$ sample packaged in a tub containing agar (without nanoparticles); $\boldsymbol{\Delta}=$ sample packaged in tub with $10 \mathrm{mg}$ of silver montmorillonite ( $\mathrm{Ag}-$ MMT); - sample packaged in tub with $15 \mathrm{mg}$ of Ag-MMT; O = sample packaged in tub with $20 \mathrm{mg}$ of Ag-MMT.

tested concentrations did not reach undesired microbial levels, allowing us to consider the MAL higher than the observation period.

Changes in the viable cell count of Pseudomonas spp. of Fior di Latte are shown in Figure 2. The silver-based packaging system was effective in inhibiting the growth of Pseudomonas spp. In fact, without silver, the concentration of bacteria increased significantly (to $10^{8} \mathrm{cfu} / \mathrm{g}$ ), whereas the active samples showed a prolonged lag phase to reach a maximum concentration of about $10^{6}$ $\mathrm{cfu} / \mathrm{g}$. The results from the fitting procedure are also reported in Table 1, along with the statistical analysis. The MAL ${ }^{\text {Pseudomonas }}$ values of the 2 control samples were statistically comparable; in both samples, Pseudomonas spp. proliferated from $10^{2}$ to $10^{8} \mathrm{cfu} / \mathrm{g}$ during the 7 -d monitoring period. In contrast, the MAL of the active samples showed significant differences. In particular,

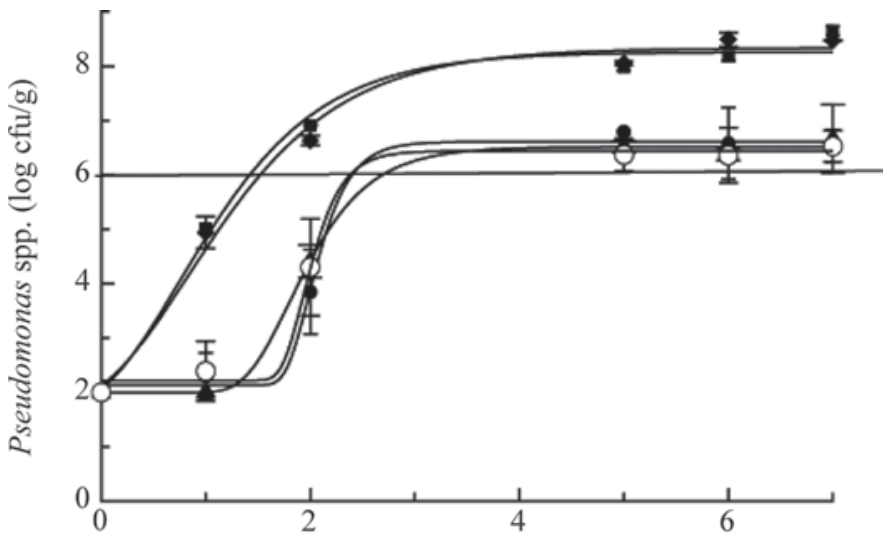

Time (d)

Figure 2. Evolution of Pseudomonas spp. count in Fior di Latte cheese during the storage period. The curves are the best fit to the experimental data. $\mathbf{\square}=$ control sample packaged in the traditional packaging; $\$$ = sample packaged in a tub containing agar (without nanoparticles); $\boldsymbol{\Lambda}=$ sample packaged in tub with $10 \mathrm{mg}$ of silver montmorillonite (Ag-MMT); $\bullet$ = sample packaged in tub with $15 \mathrm{mg}$ of Ag-MMT; $O=$ sample packaged in tub with $20 \mathrm{mg}$ of Ag-MMT.

a prolonged lag phase followed by an increase in cell numbers after $5 \mathrm{~d}$ of storage was observed in all cheeses packaged in the active systems. Similar results were reported by in vitro tests recorded with silver nanocomposites on Pseudomonadaceae (Incoronato et al., 2010), suggesting that the active packaging was not compromised by the complexity of the food product.

The silver nanoparticles did not inhibit lactic acid bacteria or coccus-shaped lactic acid bacteria. As seen in Figure 3, no marked differences were observed between the control samples and those packaged in the active systems. Within the complex microbiota of Mozzarella cheese, lactic acid bacteria are the functional microorganisms responsible for acidification of the curd through the production of lactic acid from lactose and are able to exert a probiotic action on human health (Nousiainen and Setala, 1998). With various nanopar-

Table 1. Microbiological acceptability limit (MAL; days \pm SD) for Pseudomonas spp. and total coliforms, and overall sensorial acceptability limit (SAL; days \pm SD) of Fior di Latte cheeses

\begin{tabular}{lcccc}
\hline Sample $^{1}$ & MAL $^{\text {Pseudomonas }}$ & MAL $^{\text {Coliforms }}$ & SAL $^{\text {Overall quality }}$ & Shelf life $^{2}$ \\
\hline Control & $1.42 \pm 0.11^{\mathrm{a}}$ & $1.95 \pm 0.26^{\mathrm{a}}$ & $4.85 \pm 0.72^{\mathrm{b}}$ & $1.42 \pm 0.11^{\mathrm{b}}$ \\
Control-agar & $1.52 \pm 0.11^{\mathrm{a}}$ & $2.36 \pm 0.40^{\mathrm{b}}$ & $5.26 \pm 0.89^{\mathrm{b}}$ & $1.52 \pm 0.11^{\mathrm{b}}$ \\
Nano 10 & $>7$ & $>7$ & $6.13 \pm 0.17^{\mathrm{a}}$ & $6.13 \pm 0.17^{\mathrm{a}}$ \\
Nano 15 & $>7$ & $>7$ & $6.19 \pm 0.68^{\mathrm{a}}$ & $6.19 \pm 0.68^{\mathrm{a}}$ \\
Nano 20 & $>7$ & $>7$ & $6.23 \pm 0.42^{\mathrm{a}}$ & $6.23 \pm 0.42^{\mathrm{a}}$ \\
\hline
\end{tabular}

a,b Data in columns with different superscripts are significantly different $(P<0.05)$.

${ }^{1}$ Control = sample packaged in traditional packaging; control-agar $=$ sample packaged in a tub containing agar (without nanoparticles); Nano $10=$ sample packaged in a tub with $10 \mathrm{mg}$ of silver montmorillonite (Ag-MMT); Nano 15 = sample packaged in a tub with $15 \mathrm{mg}$ of Ag-MMT; Nano $20=$ sample packaged in a tub with 20 mg of Ag-MMT.

${ }^{2}$ Shelf life (days) $=$ lowest value between the calculated MAL and SAL. 
Table 2. Cell load concentrations of total mesophilic viable counts (log cfu/g; \pm SD) attained in the stationary phase

\begin{tabular}{lccccc}
\hline & \multicolumn{3}{c}{ Sample $^{1}$} \\
\cline { 2 - 6 } Time (d) & Control & Control-agar & Nano 10 & Nano 15 & \multicolumn{1}{c}{ Nano 20} \\
\hline 0 & $4.87 \pm 0.18^{\mathrm{d}, \mathrm{A}}$ & $4.87 \pm 0.18^{\mathrm{e}, \mathrm{A}}$ & $4.87 \pm 0.18^{\mathrm{c}, \mathrm{A}}$ & $4.87 \pm 0.18^{\mathrm{c}, \mathrm{A}}$ & $4.87 \pm 0.18^{\mathrm{c}, \mathrm{A}}$ \\
1 & $6.35 \pm 0.53^{\mathrm{c}, \mathrm{A}}$ & $5.74 \pm 0.30^{\mathrm{d}, \mathrm{AB}}$ & $5.27 \pm 0.68^{\mathrm{c}, \mathrm{BC}}$ & $4.58 \pm 0.05^{\mathrm{c}, \mathrm{C}}$ & $4.71 \pm 0.01^{\mathrm{c}, \mathrm{C}}$ \\
2 & $7.77 \pm 0.31^{\mathrm{b}, \mathrm{A}}$ & $7.40 \pm 0.06^{\mathrm{c}, \mathrm{A}}$ & $5.37 \pm 0.38^{\mathrm{c}, \mathrm{B}}$ & $4.69 \pm 0.01^{\mathrm{c}, \mathrm{C}}$ & $4.79 \pm 0.04^{\mathrm{c}, \mathrm{C}}$ \\
5 & $8.62 \pm 0.48^{\mathrm{a}, \mathrm{A}}$ & $8.81 \pm 0.11^{\mathrm{a}, \mathrm{A}}$ & $7.59 \pm 0.06^{\mathrm{b}, \mathrm{B}}$ & $7.54 \pm 0.68^{\mathrm{b}, \mathrm{B}}$ & $7.21 \pm 0.14^{\mathrm{B}}$ \\
6 & $8.78 \pm 0.14^{\mathrm{a}, \mathrm{A}}$ & $8.47 \pm 0.13^{\mathrm{b}, \mathrm{B}}$ & $8.40 \pm 0.07^{\mathrm{a}, \mathrm{B}}$ & $7.76 \pm 0.05^{\mathrm{ab}, \mathrm{C}}$ & $7.96 \pm 0.02^{\mathrm{a}, \mathrm{D}}$ \\
7 & $8.97 \pm 0.12^{\mathrm{a}, \mathrm{A}}$ & $8.75 \pm 0.21^{\mathrm{ab}, \mathrm{A}}$ & $8.13 \pm 0.32^{\mathrm{a}, \mathrm{B}}$ & $8.22 \pm 0.06^{\mathrm{a}, \mathrm{B}}$ & $8.13 \pm 0.08^{\mathrm{B}}$ \\
\hline
\end{tabular}

${ }^{\mathrm{a}-\mathrm{e}}$ Data in columns with different lowercase superscripts are significantly different $(P<0.05)$.

${ }^{\mathrm{A}-\mathrm{D}}$ Data in rows with different uppercase superscripts are significantly different $(P<0.05)$.

${ }^{1}$ Control $=$ sample packaged in traditional packaging; control-agar $=$ sample packaged in a tub containing agar (without nanoparticles); Nano 10 = sample packaged in a tub with $10 \mathrm{mg}$ of silver montmorillonite (Ag-MMT); Nano 15 = sample packaged in a tub with $15 \mathrm{mg}$ of Ag-MMT; Nano 20 sample packaged in a tub with $20 \mathrm{mg}$ of Ag-MMT.

ticle manufacturing methods, different toxicity testing methods, and varying species, the results are incomparable (Lee et al., 2009). Therefore, due to the lack of literature dealing with applications of silver nanoparticles to dairy food, our findings demonstrate that extensive research is still essential.

The yeast counts (data not shown) were $10^{2} \mathrm{cfu} / \mathrm{g}$ in all samples initially but increased during the last days of the storage time, following different trends. A period of stability occurred in yeast counts in all samples during the first $2 \mathrm{~d}$, followed by a considerable increase in the control samples. In contrast, for active samples, the cell load remained approximately constant during the entire storage period. Italy has not established a standard for this group of microorganisms in Mozzarella cheese; however, it is known that yeasts have an important role in the spoilage of cheese. Yeasts can play a positive or negative role in fermented dairy products by contributing to cheese ripening or by causing product spoilage (Fleet, 1990; Jakobsen and Narvhus, 1996). Indeed, yeasts can cause spoilage of other cheese types as a result of gas (open texture or slits) and off-flavor formation (Seiller, 2002). Lactose-fermenting Kluyveromyces and galactose-fermenting Saccharomyces yeasts tend to spoil fresh cheeses, such as soft cheeses and pasta filata cheese, during the first few days of maturation, when lactose and galactose are more readily available (Liu and Tsao, 2009).

With regard to total microbial counts in the packaged dairy products, considerable proliferation was observed in the control samples and a longer lag phase was observed in the other packaged products. The cell loads attained in the stationary phase are reported in Table 2.

With respect to $\mathrm{pH}$ (data not shown), the values ranged between 5.87 and 5.89, without substantial differences between the samples; therefore, it is reasonable to assume that the antimicrobial effects of the investi- gated active compounds cannot be ascribed to a change in $\mathrm{pH}$.
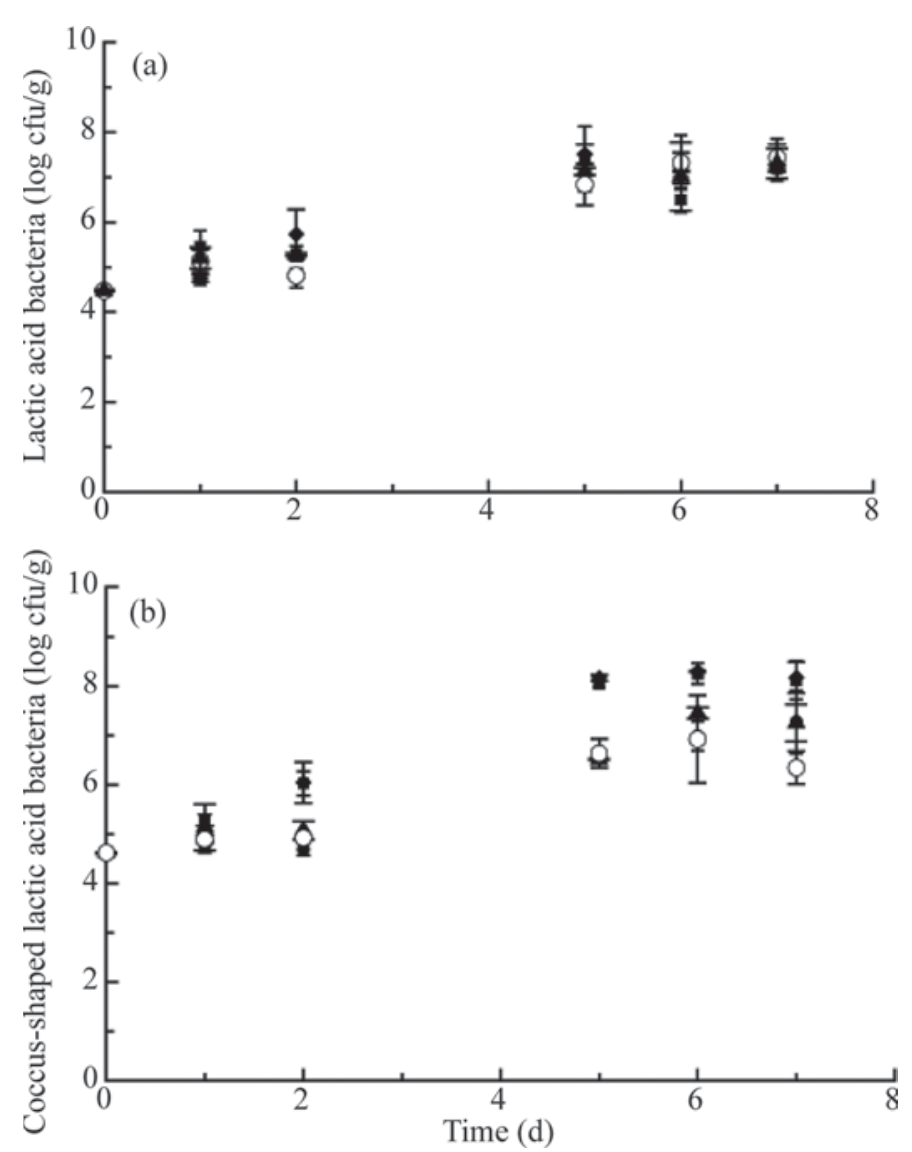

Figure 3. Evolution of (a) lactic acid bacteria and (b) coccusshaped lactic acid bacteria in Fior di Latte cheese during the storage period. = control sample packaged in the traditional packaging; = sample packaged in a tub containing agar (without nanoparticles); $\boldsymbol{\Delta}=$ sample packaged in tub with $10 \mathrm{mg}$ of silver montmorillonite (AgMMT); = sample packaged in tub with $15 \mathrm{mg}$ of Ag-MMT; O = sample packaged in tub with $20 \mathrm{mg}$ of $\mathrm{Ag}$-MMT. 
Table 3. Sensorial acceptability limit (days \pm SD) for each Fior di Latte attribute

\begin{tabular}{lcccc}
\hline Sample $^{1}$ & Color & Odor & Consistency & $\begin{array}{c}\text { Overall } \\
\text { acceptability }\end{array}$ \\
\hline Control & $6.39 \pm 1.02^{\mathrm{a}}$ & $5.53 \pm 0.46^{\mathrm{a}}$ & $5.13 \pm 0.23^{\mathrm{c}}$ & $4.85 \pm 0.72^{\mathrm{b}}$ \\
Control-agar & $6.32 \pm 0.83^{\mathrm{a}}$ & $5.38 \pm 1.95^{\mathrm{a}}$ & $5.69 \pm 0.19^{\mathrm{bc}}$ & $5.26 \pm 0.89^{\mathrm{ab}}$ \\
Nano 10 & $5.74 \pm 0.20^{\mathrm{a}}$ & $5.94 \pm 0.68^{\mathrm{a}}$ & $6.77 \pm 0.60^{\mathrm{abc}}$ & $6.13 \pm 0.17^{\mathrm{a}}$ \\
Nano 15 & $5.75 \pm 1.86^{\mathrm{a}}$ & $6.15 \pm 0.84^{\mathrm{a}}$ & $7.18 \pm 0.62^{\mathrm{ab}}$ & $6.19 \pm 0.68^{\mathrm{a}}$ \\
Nano 20 & $6.72 \pm 0.59^{\mathrm{a}}$ & $6.58 \pm 0.71^{\mathrm{a}}$ & $7.50 \pm 1.71^{\mathrm{a}}$ & $6.23 \pm 0.42^{\mathrm{a}}$ \\
\hline
\end{tabular}

${ }^{\mathrm{a}-\mathrm{c}}$ Data in columns with different superscript letters are significantly different $(P<0.05)$.

${ }^{1} \mathrm{Control}=$ sample packaged in traditional packaging; control-agar $=$ sample packaged in a tub containing agar (without nanoparticles); Nano $10=$ sample packaged in a tub with $10 \mathrm{mg}$ of silver montmorillonite (Ag-MMT); Nano 15 = sample packaged in a tub with $15 \mathrm{mg}$ of Ag-MMT; Nano $20=$ sample packaged in a tub with 20 $\mathrm{mg}$ of Ag-MMT.

\section{Sensory Analysis}

Figure 4 shows the overall quality during storage of Fior di Latte cheese samples. The curves shown were obtained by the fitting procedure. The results of the sensorial limits for each attribute are listed in Table 3 ; odor, color, and consistency played a similar role in determining the overall acceptability of the product. Based on Figure 4, we can infer that the active packaging systems investigated in this study exerted good effects in terms of overall quality. In fact, although the control samples became unacceptable after about $5 \mathrm{~d}$ of storage, the Fior di Latte packaged in the active systems and stored under the same storage conditions

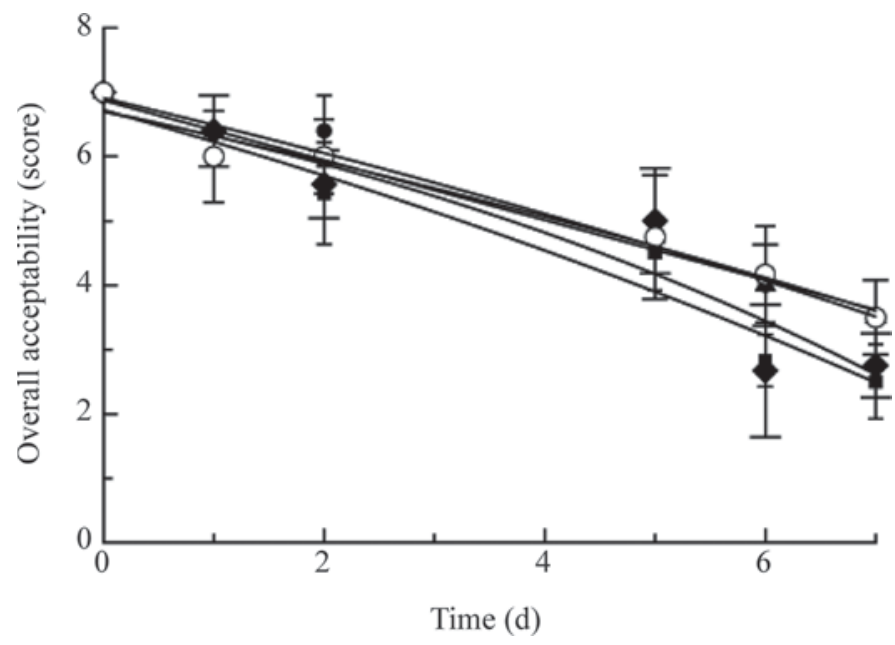

Figure 4. Evolution of the overall quality in Fior di Latte cheese during the storage period. The curves are the best fit to the experimental data. = control sample packaged in the traditional packaging; = sample packaged in a tub containing agar (without nanoparticles); $\boldsymbol{\Delta}=$ sample packaged in tub with $10 \mathrm{mg}$ of silver montmorillonite ( $\mathrm{Ag}$ MMT); $\bullet$ sample packaged in tub with $15 \mathrm{mg}$ of Ag-MMT; $\mathrm{O}=$ sample packaged in tub with $20 \mathrm{mg}$ of Ag-MMT. received an acceptable sensory score for more than 6 d.

\section{Shelf-Life Determination}

Table 1 also shows the shelf-life values, calculated as the lowest value between $\mathrm{MAL}^{\text {Coliforms }}$, MAL ${ }^{\text {Pseudomonas, }}$ and SAL ${ }^{\text {Overall quality }}$, as reported in other experimental works on dairy products (Conte et al., 2009; Del Nobile et al., 2009). For all the Fior di Latte cheese samples packaged in the active systems, the viable cell concentrations of pseudomonads and total coliforms were below the threshold during the entire observation period, suggesting that the antimicrobial nanoparticles were effective in preventing microbial proliferation, with comparable effects at all tested concentrations. The contamination of Fior di Latte cheese by Pseudomonas spp. is the major concern for product shelf life (Bevilacqua et al., 2007). Therefore, for the control samples, the proliferation of pseudomonads represented the limiting factor for product acceptability, whereas, for the Fior di Latte packaged in the active systems, the factor limiting shelf life is sensorial quality.

\section{CONCLUSIONS}

The effectiveness of new antimicrobial packaging systems on microbial and sensorial quality deterioration of Fior di Latte cheese was evaluated. Silver nanoparticles, previously investigated by in vitro test, were analyzed as the active agent under working conditions. Shelflife tests were run at $10^{\circ} \mathrm{C}$ to monitor the cell loads of spoilage and functional dairy microorganisms as well as the sensorial quality of cheeses. Under the tested conditions, our results showed an increase in the shelf life of all active-packaged Fior di Latte samples, confirming that the investigated substance may exert an inhibitory effect on the growth of spoilage microorganisms without affecting the functional dairy microbiota and sensory characteristics. Considering the suitability of 
the obtained active systems as food contact materials, further work should be undertaken to calculate the minimum amount of active Ag-MMT nanoparticles able to prolong shelf life. Moreover, the partition coefficient of silver between the agar hydrogel and the brine solution and between the brine and the food product should be calculated to allow a complete evaluation of the ion diffusion process and consequently assess the actual amount of silver in contact with food to ensure compliance with the European Union regulation.

\section{ACKNOWLEDGMENTS}

This work was financially supported by the Ministero dell'Economia e delle Finanze, Ministero dell'Istruzione, dell'Università e della Ricerca Scientifica e Tecnologica by the project Legge 297/99 Art. 12, DD n. $1172-07$ November 2008, GU n. 71 of 26-3-2009 - suppl. Ordinario n. 37; "Tecnologie per il Packaging Bioattivo di Prodotti Lattiero Caseari Freschi Pugliesi” DM 29040.

\section{REFERENCES}

Albrecht, M. A., C. W. Evan, and C. L. Raston. 2006. Green chemistry and the health implications of nanoparticles. Green Chem. 8:417-432.

Altieri, C., C. Scrocco, M. Sinigaglia, and M. A. Del Nobile. 2005. Use of chitosan to prolong Mozzarella cheese shelf life. J. Dairy Sci. 88:2683-2688.

An, J., M. Zhang, S. Wang, and J. Tang. 2008. Physical, chemical and microbiological changes in stored green asparagus spears as affected by coating of silver nanoparticles-PVP. Lebenson. Wiss. Technol. 41:1100-1107.

Bevilacqua, A., M. R. Corbo, and M. Sinigaglia. 2007. Combined effects of modified atmosphere packaging and thymol for prolonging the shelf life of caprese salad. J. Food Prot. 70:722-728.

Bishop, J. R., and C. H. White. 1986. Assessment of dairy product quality and potential shelf life - A review. J. Food Prot. 49:739753.

Bjarnsholt, T., K. Kirketerp-Moller, S. Kristiansen, R. Phipps, A. Nielsen, P. Jensen, N. Hoiby, and M. Givskov. 2007. Silver against Pseudomonas aeruginosa biofilms. APMIS 115:921-928.

Castellano, J. J., S. M. Shafii, F. Ko, G. Donate, T. E. Wright, R. J. Mannari, W. G. Payne, D. J. Smith, and M. C. Robson. 2007. Comparative evaluation of silver-containing antimicrobial dressings and drugs. Int. Wound J. 4:114-122.

Coma, V. 2008. Bioactive packaging technologies for extended shelf life of meat-based products. Meat Sci. 78:90-103.

Conte, A., D. Gammariello, S. Di Giulio, M. Attanasio, and M. A. Del Nobile. 2009. Active coating and modified-atmosphere packaging to extend the shelf life of Fior di Latte cheese. J. Dairy Sci. 92:887-894.

Conte, A., C. Scrocco, M. Sinigaglia, and M. A. Del Nobile. 2007. Innovative active packaging systems to prolong the shelf life of Mozzarella cheese. J. Dairy Sci. 90:2126-2131.

Corbo, M. R., M. A. Del Nobile, and M. Sinigaglia. 2006. A novel approach for calculating shelf life of minimally processed vegetables. Int. J. Food Microbiol. 106:69-73.

Corradini, C., and N. Innocente. 2002. Parametri chemiometrici e descrittori sensoriali del Montasio DOP. Notiziario Ersa 4:43-45.

Damm, C., H. Münstedt, and A. Rösch. 2008. The antimicrobial efficacy of polyamide 6/silver-nano- and microcomposites. Mater. Chem. Phys. 108:61-66.
Darroudi, M., M. B. Ahmad, K. Shameli, A. H. Abdullah, and N. A. Ibrahim. 2009. Synthesis and characterization of UV-irradiated silver/montmorillonite nanocomposites. Solid State Sci. 11:16211624.

Del Nobile, M. A., D. Gammariello, A. Conte, and M. Attanasio. 2009. A combination of chitosan, coating and modified atmosphere packaging for prolonging Fior di Latte cheese shelf life. Carbohydr. Polym. 78:151-156.

Feng, Q. L., J. Wu, G. Q. Chen, F. Z. Cui, T. N. Kim, and J. O. Kim. 2000. A mechanistic study of the antibacterial effect of silver ions on Escherichia coli and Staphylococcus aureus. J. Biomed. Mater. Res. 52:662-668.

Fernandez, A., E. Soriano, G. Lopez.Carballo, P. Picouet, E. Lloret, R. Gavara, and P. Hernandez-Munoz. 2009. Preservation of aseptic conditions in absorbent pads by using silver nanotechnology. Food Res. Int. 42:1105-1112.

Fleet, G. H. 1990. Yeasts in dairy products. J. Appl. Bacteriol. 68:199-211.

Gammariello, D., S. Di Giulio, A. Conte, and M. A. Del Nobile. 2008. Effects of natural compounds of microbial safety and sensory quality of Fior di Latte cheese, a typical Italian cheese. J. Dairy Sci. 91:4138-4146.

Gong, P., H. Li, X. He, K. Wang, J. Hu, and W. Tan. 2007. Preparation and antibacterial activity of $\mathrm{Fe}_{3} \mathrm{O}_{4} \mathrm{Ag}$ nanoparticles. Nanotechnology 18:604-611.

Gu, H., P. L. Ho, E. Tong, L. Wang, and B. Xu. 2003. Presenting vancomycin on nanoparticles to enhance antimicrobial activities. Nano Lett. 3:1261-1263.

Hindi, K. M., T. Siciliano, S. Durmus, M. J. Panzer, D. A. Medvetz, D. V. Reddy, L. A. Hogue, C. E. Hovis, J. K. Hilliard, R. J. Mallet, C. A. Tessier, C. L. Cannon, and W. J. Youngs. 2008. Synthesis, stability, and antimicrobial studies of electronically tuned silver acetate N-heterocyclic carbenes. J. Med. Chem. 51:1577-1583.

Incoronato, A. L., G. G. Buonocore, A. Conte, M. Lavorgna, and M. A. Del Nobile. 2010. Active systems based on silver/montmorillonite nanoparticles embedded into bio-based polymer matrices for packaging applications. J. Food Prot. 73:2256-2262..

Jakobsen, M., and J. Narvhus. 1996. Yeasts and their possible beneficial and negative effects on the quality of dairy products. Int. Dairy J. 6:755-768.

Kascatan-Nebioglu, A., M. J. Panzner, C. A. Tessier, C. L. Cannon, and W. J. Youngs. 2007. N-heterocyclic carbene-silver complexes: A new class of antibiotics. Coord. Chem. Rev. 251:884-895.

Kumar, R., and H. Münstedt. 2005. Polyamide/silver antimicrobials: Effect of crystallinity on the silver ion release. Polym. Int 54:1180-1186.

Lansdown, A. B. G. 2002. Silver I: Its antibacterial properties and mechanism of action. J. Wound Care 11:125-130.

Lee, S., J. Lee, K. Kim, S. J. Sim, M. B. Gu, Y. Ji, and J. Lee. 2009 Eco-toxicity of commercial silver nanopowders to bacterial and yeast strains. Biotechnol. Bioproc. Eng. 14:490-495.

Li, H., F. Li, L. Wang, J. Sheng, Z. Xin, L. Zhao, H. Xiao, Y. Zheng, and Q. Hu. 2009. Effect of nano-packing on preservation quality of Chinese jujube (Ziziphus jujuba Mill. var. inermis (Bunge) Rehd). Food Chem. 114:547-552.

Liu, S. Q., and M. Tsao. 2009. Inhibition of spoilage yeasts in cheese by killer yeast Williopsis saturnus var. saturnus. Int. J. Food Microbiol. 131:280-282.

Lopez-Rubio, A., E. Almenar, P. Hernandez-Munoz, J. M. Lagaron, R. Catala, and R. Gavara. 2006. Overview of active polymerbased packaging technologies for food applications. Food Rev. Int. 20:357-387.

Nousiainen, J., and J. Setala. 1998. Lactic acid bacteria as animal probiotics. Pages 437-473 in Lactic Acid Bacteria: Microbiology and Functional Aspects. 2nd ed. S. Salminen and A. von Wright, ed. Marcel Dekker Inc., New York, NY.

Panacek, A., L. Kvitek, R. Prucek, M. Kolar, R. Vecerova, N. Pizurova, V. K. Sharma, T. Nevecna, and R. Zboril. 2006. Silver colloid nanoparticles: Synthesis, characterization, and their antibacterial activity. J. Phys. Chem. B 110:16248-16253. 
Retchkiman-Schabes, P. S., G. Canizal, R. Becerra-Herrera, C. Zorrilla, H. B. Liu, and J. A. Ascencio. 2006. Biosynthesis and characterization of Ti/Ni bimetallic nanoparticles. Opt. Mater. 29:95-99.

Seiller, H. 2002. Yeasts in milk and dairy products. Pages 2761-2769 in Encyclopedia of Dairy Science. Vol. 4. H. Roginski, J. W. Fuquay, and P. F. Fox, ed. Academic Press, New York, NY.
Spano, G., E. Goffredo, L. Beneduce, D. Tarantino, A. Dupuy, and S. Massa. 2003. Fate of Escherichia coli O157:H7 during the manufacture of Mozzarella cheese. Lett. Appl. Microbiol. 36:73-76.

Tamine, A. Y. 2000. Cheese. Pages 372-403 in Encyclopedia of Food Microbiology. R. K. Robinson, C. C. Batt, and P. D. Patel, ed. Academic Press, London, UK. 